Economics Development Analysis Journal

\title{
Mekanisme Transmisi Kebijakan Moneter dalam Mempengaruhi Inflasi dan Pertumbuhan Ekonomi di Indonesia
}

\author{
Rifky Yudi Setiawan $^{1 凶}$, Karsinah ${ }^{2}$
}

Jurusan Ekonomi Pembangunan, Fakultas Ekonomi, Universitas Negeri Semarang

\begin{tabular}{|c|c|}
\hline Info Artikel & Abstrak \\
\hline $\begin{array}{l}\text { Keywords: } \\
\text { Monetary Police, } \\
\text { Conventional, Sharia, } \\
\text { Inflation, Economic Growth, } \\
\text { Vector Error Correction } \\
\text { Model (VECM) }\end{array}$ & $\begin{array}{l}\text { Sejak dikeluarkannya UU Bank Indonesia yang baru tahun } 1999 \text {, Bank Indonesia telah diberi } \\
\text { amanah sebagai otoritas moneter ganda yang dapat menjalankan kebijakan moneter konvensional } \\
\text { maupun syariah. Sejak saat itu perbankan dan keuangan syariah berkembang pesat.Penelitian ini } \\
\text { bertujuan untuk melihat alur transmisi kebijakan moneter dari sisi konvensional dan syariah dalam } \\
\text { mempengaruhi inflasi dan pertumbuhan ekonomi, yang kemudian membandingkan keduanya. } \\
\text { Hasil penelitian menunjukkan jalur konvensional memiliki alur sesuai dengan teori transmisi } \\
\text { kebijakan moneter yang ada hingga mempengaruhi inflasi dan pertumbuhan ekonomi, sedangkan } \\
\text { jalur syariah belum mempunyai alur yang sesuai dengan teori kebijakan moneter yang ada. } \\
\text { Berdasarkan hasil VECM variabel syariah dapat menurunkan laju inflasi dan meningkatkan } \\
\text { pertumbuhan ekonomi, sedangkan variabel konvensional dapat menurunkan laju inflasi akan } \\
\text { tetapi menahan laju pertumbuhan ekonomi. Kemudian berdasarkan hasil FEVD jalur } \\
\text { konvensional lebih berpengaruh dalam mengendalikan pertumbuhan ekonomi dan inflasi dengan } \\
\text { masing-masing kontribusi sebesar } 50,5 \% \text { dan } 19,97 \% \text {, sedangkan jalur syariah masing-masing } \\
\text { sebesar } 29,07 \% \text {. dan } 19,47 \% \text {. }\end{array}$ \\
\hline
\end{tabular}

\begin{abstract}
Since New Banking Act in 1998, Indonesia has implemented a dual banking system, where conventional and Islamic banks can operate side by side throughout Indonesia. With the implementation of Bank of Indonesia's Act in 1999, Bank of Indonesia has a dual mandate to conduct both conventional and Islamic monetary policies. Since then, the Islamic banking and finance has been growing rapidly. The aim of this study is to see how transmission channel of monetary policy from side of conventional and Sharia channel to Influence Inflation and Economic Growth compare them both. The results showed the conventional channel is worked according to the theory of transmission mechanism of monetary policy that affect the final target inflation and economic growth, whereas Sharia channel does not worked according to the monetary policy. Based on the results of VECM on Sharia channel variable can reduce the inflation and increase the economic growth at the same time, while the variable of conventional channel can reduce the inflation but also reduce the economic growth at the same time. Then based on the results of FEVD conventional channel is more effective in controlling the economic growth and the inflation with contribution of $50.5 \%$ and $19.97 \%$. while the Islamic bank financing channel with contribution of $29.07 \%$ and $19.47 \%$.
\end{abstract}

(C) 2016 Universitas Negeri Semarang

\footnotetext{
${ }^{\triangle}$ Alamat korespondensi:

Ruang Jurnal,Gedung L FE UNNES Sekaran Gunungpati

Semarang 50229, Indonesia

E-mail: rifkyyudis@gmail.com
} 


\section{PENDAHULUAN}

Sejak dikeluarkannya UU perbankan No. 10 Tahun 1998, Indonesia secara de jure menerapkan sistem perbankan ganda. Pengertian dari sistem perbankan ganda atau dual banking system adalah dimana bank konvensional dan bank syariah dapat beroperasi secara bersamaan. Selanjutnya terbit UU No. 23 Tahun 1999 yang memberikan amanah kepada Bank Indonesia sebagai otoritas moneter ganda yang dapat menjalankan kebijakan moneter secara konvensional maupun syariah.

Sejak kebijakan moneter dapat berjalan berdampingan baik secara konvensional dan syariah, menyebabkan perkembangan perbankan dan keuangan syariah berkembang dengan pesat di
Indonesia. Perkembangan perbankan syariah di Indonesia dapat dilihat dari jumlah aset, Dana Pihak Ketiga, dan pembiayaan. Hingga akhir tahun 2014, jumlah aset bank syariah telah mencapai 272.343 miliar rupiah, pembiayaan yang disalurkan mencapai 262.708 miliar rupiah dan DPK tumbuh mencapai 217.858 miliar rupiah. Perkembangan industri perbankan syariah mengakibatkan transmisi kebijakan moneter tidak hanya memengaruhi perbankan konvensional tetapi juga memengaruhi perbankan syariah, sehingga Bank Indonesia memiliki tanggung jawab untuk menjalankan operasi moneter ganda baik secara konvensional maupun syariah.

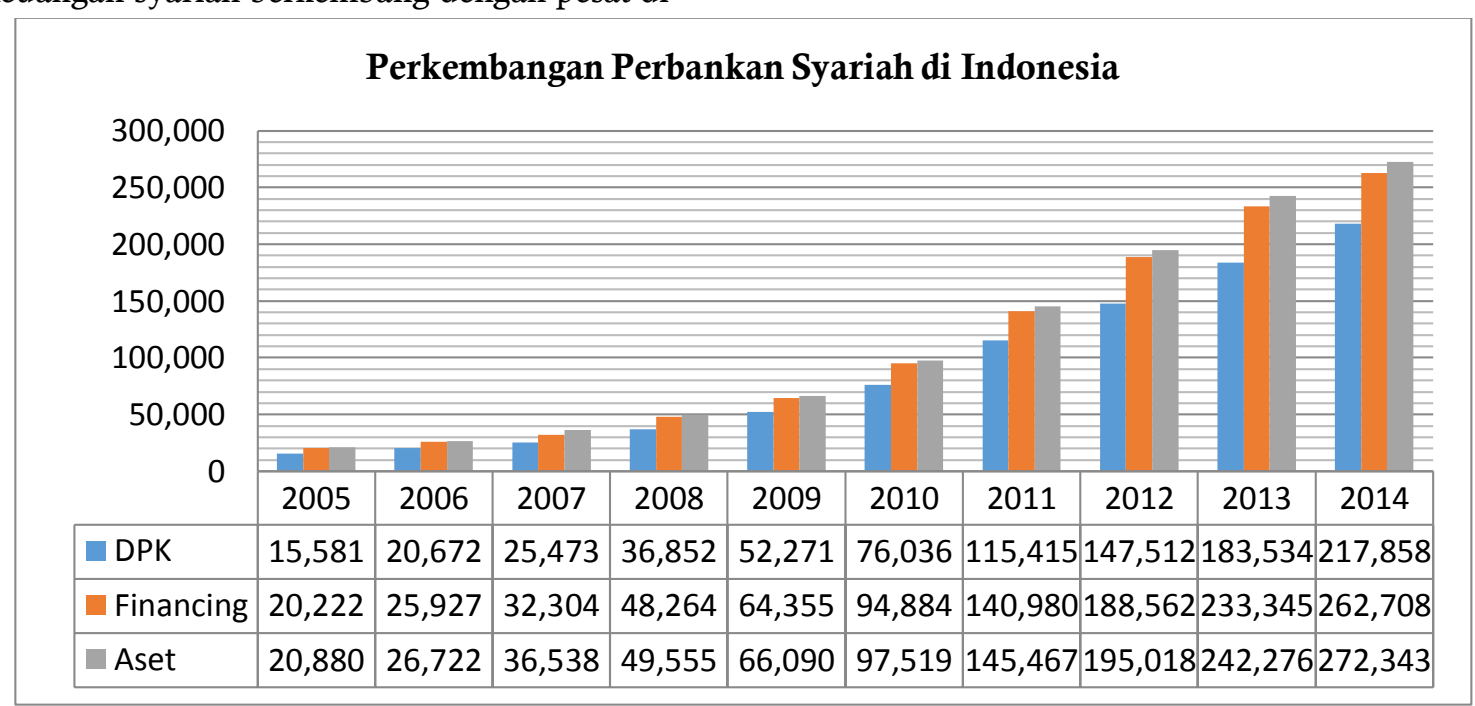

Gambar 1. Perkembangan Perbankan Syariah di Indonesia

Sumber: Bank Indonesia

Instrumen moneter syariah pertama yang diperkenalkan pada awal tahun 2000 yaitu sertifikat Wadiah Bank Indonesia dengan akad Wadiah, yang dimaksud akad wadiah yaitu perjanjian penitipan dana antara pemilik dana dengan pihak penerima titipan yang dipercaya untuk menjaga dana tersebut. Berdasarkan peraturan Bank Indonesia No. 10 tahun 2008 instrumen SWBI diganti menjadi Sertifikat Bank

Indonesia Syariah (SBIS) dengan akad jualah, yang dimaksud akad jualah yaitu janji atau komitmen untuk memberikan reward tertentu atas pencapaian hasil yang ditentukan dari satu pekerjaan. Fee SBIS saat ini masih merujuk pada tingkat suku bunga SBI. Tingkat fee SBIS berperan dalam rate kebijakan untuk bank syariah yang akan mempengaruhi pendanaan dan pembiayaan melalui pasar uang antar bank syariah (PUAS) dan kemudian mempengaruhi perbankan dalam menyalurkan pembiayaan nya.

Di Indonesia Sejak diterbitkannya UU No. 23 Tahun 1999 tentang Bank Indonesia yang kemudian di amandemen menjadi UU No. 3 Tahun 2004, tujuan Bank Indonesia yang sebelumnya memiliki tujuan ganda (multiple target) yaitu pertumbuhan ekonomi, stabilitas harga dan perluasan kesempatan kerja, menjadi lebih fokus dalam pencapaian sasaran tunggal (single target) yaitu mencapai dan memelihara kestabilan rupiah. Sejak tahun 2000, Bank Indonesia sudah mulai menentukan dan mengumumkan sasaran inflasi sebagai sasaran akhir kebijakan, hanya saja bank 
indonesia secara resmi mengumumkan penerapan Inflation Targeting Framework (ITF) mulai 1 Juli 2005. Inflation Targeting Framework telah diterapkan oleh sebagian besar bank sentral, khususnya di negara maju, dalam dua puluh tahun terakhir sehingga transmisi suku bunga (interest rate passthough) telah banyak menarik perhatian dari sebelumnya. Penerapan Inflation Targeting Framework secara empiris terbukti di beberapa negara maju maupun negara berkembang dapat mengontrol inflasi pada tingkat yang relatif rendah karena tingkat inflasi yang tinggi akan memiliki pengaruh yang besar terhadap pertumbuhan ekonomi (Aydın, 2016).

Namun demikian, negara-negara maju hanya membukukan pertumbuhan ekonomi yang juga rendah sekitar 2-3 persen, sedangkan, beberapa negara berkembang dapat mencapai pertumbuhan ekonomi yang lebih tinggi sekitar 4-6 persen. Negara yang paling menonjol pertumbuhan ekonominya adalah tiongkok, disusul oleh argentina. Sementara itu, pertumbuhan ekonomi Indonesia cuku stabil di kisaran 4-6 persen, termasuk pada masa krisis finansial global tahun 2009

Semakin berkembangnya perbankan syariah, transmisi kebijakan moneter tidak hanya mempengaruhi perbankan konvensional saja, namun juga mempengaruhi perbankan syariah, karena mekanisme transmisi dapat juga melawati jalur syariah. Instrumen kebijakan moneter ganda juga tidak terbatas hanya menggunakan suku bunga saja, tetapi dapat pula menggunakan bagi hasil atau margin fee. Dengan demikian, dalam sistem moneter ganda, interest rate pass-through lebih tepat disebut policy rate pass-through, dimana policy rate untuk konvensional menggunakan suku bunga, sedangkan policy rate untuk syariah dapat menggunakan bagi hasil, margin, atau fee.

Berdasarkan latar belakang yang telah diuraikan makan pertanyaan penelitian yang ditetapkan adalah sebagai berikut:

1. Bagaimana alur mekanisme transmisi kebijakan moneter jalur konvensional dan syariah dalam mempengaruhi inflasi dan pertumbuhan ekonomi di Indonesia.

2. Bagaimana pengaruh jangka pendek dan jangka panjang variabel jalur konvensional dan syariah dalam mempengaruhi inflasi dan pertumbuhan ekonomi di Indonesia.

3. Bagaimana perbandingan besaran pengaruh variabel jalur konvensional dan syariah dalam mempengaruhi inflasi dan pertumbuhan ekonomi di Indonesia.

\section{METODE PENELITIAN}

Penelitian ini merupakan jenis penelitian dengan metode kuantitatif. Jenis data yang digunakan dalam penelitian ini adalah data sekunder dalam bentuk deret waktu bulanan (monthly time series) pada periode Januari 2006 sampai dengan desember 2014.

Data yang digunakan antar lain Indeks Harga Konsumen (IHK), Industrial Production Index (IPI) Proxy Pertumbuhan Ekonomi, Variabel Konvensional: Suku Bunga Sertifikat Bank Indonesia (SBI), Suku Bunga Pasar Uang Antar Perbankan Konvensional (PUAB), Suku Bunga Kredit (INT), Kredit yang disalurkan. Variabel Syariah: fee Sertifikat Bank Indonesia Syariah (SBIS), Bagi Hasil Pasar Uang Antar Perbankan Syariah (PUAS), Bagi Hasil Pembiayaan Perbankan Syariah (PLS), dan Pembiayaan yang disalurkan.

Metode analisis yang digunakan dalam penelitian ini adalah metode Vector Error Correction Model (VECM) yang dibantu dengan E-views 9. Tahapan metode VECM adalah Uji Pra-Estimasi yang meliputi Uji Stasionaritas, Uji Lag Optimal, Uji kointegritas. Setelah dilakukan uji pra-estimasi baru dilakukan uji VECM untuk melihat hubungan jangka pendek dan jangka panjang baik variabel konvensional maupun syariah. Setelah dilakukan analisis VECM. Yang selanjutnya adalah uji kausalitas garnger untuk melihat alur mekanisme transmisi kebijakan moneter di Indonesia baik dari sisi konvensional maupun syariah. Setelah dilakukan analisis Kausalitas Granger adalah analisis FEVD untuk melihat perbandingan besaran pengaruh antara variabel konvensional dan syariah dalam mempengaruhi inflasi dan pertumbuhan ekonomi di Indonesia.

\section{Model Penelitian}



berikut

Model awal penelitian ini adalah sebagai

\section{Model awal sasaran akhir inflasi}

Ln CPI $=\beta_{0}+\beta_{1}$ SBIS $+\beta_{2}$ PUAS $+\beta_{3}$ PLS $+\beta_{4}$ ln Finance $+\beta_{5} \mathrm{SBI}+\beta_{6} \mathrm{PUAB}+\beta_{7} \mathrm{INT}+\beta_{8}$ LnLoan $+\varepsilon$.

2. Model awal sasaran akhir pertumbuhan ekonomi

Ln IPI $=\beta_{0}+\beta_{1}$ SBIS $+\beta_{2}$ PUAS $+\beta_{3}$ PLS $+\beta_{4}$ ln Finance $+\beta_{5}$ SBI $+\beta_{6}$ PUAB $+\beta_{7}$ INT $+\beta_{8}$

Ln Loan $+\varepsilon$.

\section{Keterangan}

Ln IPI = Logaritma Natural dari Industrial Production Indeks sebagai proxy pertumbuhan ekonomi

Ln IHK = Logaritma Natural dari Indeks Harga Konsumen sebagai proxy inflasi

SBIS = Tingkat Bagi Hasil Sertifikat Bank Indonesia Syariah (persen)

PUAS = Tingkat Bagi Hasil Pasar Uang Antar Perbankan Syariah (Persen)

PLS = Tingkat Bagi Hasil Pembiayaan

Ln Finance $=$ Logaritma Natiural Pembiayaan yang disalurkan Perbankan Syariah (Miliar)

SBI = Suku Bunga Sertifikat Bank Indonesia (Persen)
PUAB = Suku Bunga Pasar Uang Antar Perbankan (persen)

INT = Suku bunga kredit perbankan (persen)

Ln Loan= Logaritma Natural Kredit yang disalurkan Perbankan konvensional

$$
\begin{array}{ll}
\beta_{1}-\beta_{8} & =\text { Koefisien } \\
\beta_{0} & =\text { Konstanta } \\
\varepsilon & =\text { Error Trem }
\end{array}
$$

\section{HASIL DAN PEMBAHASAN}

\section{Uji Pra-Estimasi VECM}

Uji Stasioneritas Data

Metode pengujian yang digunakan untuk melakukan uji stasioneritas data dalam penelitian ini adalah uji ADF (Augmented Dickey Fuller) dengan menggunakan taraf nyata lima persen. Jika nilai t-ADF lebih kecil dari nilai kritis MacKinnon, maka dapat disimpulkan bahwa data yang digunakan stasioner (tidak mengandung akar unit). Berdasarkan uji ADF menunjukkan bahwa variabel-variabel yang digunakan dalam penelitian tidak seluruhnya stasioner pada tingkat level. Setelah dilakukan uji pada tingkat First Different, baru semua data/variabel stasioner pada taraf nyata lima persen. Artinya data yang digunakan dalam penelitian ini telah terintegrasi pada ordo satu atau dapat disingkat menjadi I (1).

Tabel 1. Hasil Pengujian Akar Unit pada Tingkat Level dan First Different

\begin{tabular}{ccccc}
\hline & \multicolumn{2}{c}{ Tingkat Level } & \multicolumn{2}{c}{ First Different } \\
\cline { 2 - 5 } VARIABEL & ADF Statistik & Mc. Kinnon 5\% & ADF Statistik & \multicolumn{1}{c}{ Mc. Kinnon } \\
& & & & \\
\hline INT & -3.0112 & -3.4536 & -5.28609 & -3.45276 \\
Ln IHK & -2.4036 & -3.4524 & -10.56087 & -3.45276 \\
Ln IPI & -3.2227 & -3.4524 & -12.35577 & -3.45276 \\
Kredit & -4.6404 & -3.4578 & -4.051577 & -3.45538 \\
Ln Pembiayaan & -1.2062 & -3.4536 & -3.574801 & -3.4536 \\
PLS & -5.0663 & -3.4532 & -8.392005 & -3.4540 \\
PUAB & -2.4224 & -3.4573 & -3.603984 & -3.4573 \\
PUAS & -3.7295 & 3.4528 & -14.9452 & -3.45276 \\
SBI & -2.3271 & -3.4528 & -6.091572 & -3.45276 \\
SBIS & -3.5525 & -3.4524 & -3.552497 & -3.45236 \\
\hline
\end{tabular}

\section{Uji Lag Optimal}

Pengujian selanjutnya adalah penentuan lag optimal, Dalam penelitian ini, penulis akan menggunakan pedoman dari Gujarati 2, (2007: 112) dimana lag dengan nilai AIC terendah adalah yang paling optimal. Dalam penelitian ini maka 
pengujian panjang lag akan dilakukan dari lag 1 hingga lag 8 baik untuk model Pertumbuhan Ekonomi dan Inflasi. Lag dari nilai AIC terendah itulah lag yang paling optimal, sehingga lag tersebut yang akan digunakan dalam pengujian

Tabel 2. Lag Optimal Inflasi

\begin{tabular}{cc}
\hline Lag & AIC \\
\hline 0 & 13.41003 \\
1 & -3.304856 \\
2 & -3.880064 \\
3 & -3.805785 \\
4 & -3.677261 \\
5 & -4.037099 \\
6 & -4.709178 \\
7 & -7.107650 \\
8 & $-8.631940^{*}$ \\
\hline
\end{tabular}

Tabel 3 dan 4 menunjukkan hasil dari pengujian lag 1 sampai dengan lag 8 untuk model Inflasi dan Pertumbuhan Ekonomi, hasil pengujian lag yang paling optimal untuk model inflasi dan pertumbuhan ekonomi dengan kriteria AIC adalah di Lag ke 8, karena pada lag ke-8 nilai AIC adalah yang terendah.

\section{Uji Kointegritas}

Langkah selanjutnya adalah pengujian kointegrasi antar variabel untuk menentukan Metode yang nantinya akan digunakan. pengujian kointegrasi dilakukan dengan menggunakan selang

Tabel 4. Hasil Uji Kointegras Inflasi

\begin{tabular}{ll}
\hline Trace Statistic & Critical Value \\
\hline 924.3990 & 228.2979 \\
638.8994 & 187.4701 \\
434.8703 & 150.5585 \\
315.6465 & 117.7082 \\
229.8638 & 88.80380 \\
167.8410 & 63.87610 \\
111.7362 & 42.91525 \\
62.24303 & 25.87211 \\
18.27199 & 12.51798 \\
\hline
\end{tabular}

selanjutnya baik untuk model inflasi ataupun pertumbuhan ekonomi. Pengujian lag optimal untuk model inflasi dan pertumbuhan ekonomi dapat dilihat pada tabel 2 dan 3.

Tabel 3. Lag Optimal Pertumbuhan Ekonomi

\begin{tabular}{ll}
\hline Lag & AIC \\
\hline 0 & 13.48272 \\
1 & -3.290067 \\
2 & -3.964436 \\
3 & -3.945187 \\
4 & -3.915200 \\
5 & -4.088341 \\
6 & -4.620366 \\
7 & -6.916124 \\
8 & $-8.629120^{*}$ \\
\hline
\end{tabular}

optimal sesuai dengan pengujian sebelumnya. dalam penelitian uji kointegritas yang digunakan adalah dengan menggunakan Johnsonsen Cointegration Test.

Uji Kointegrasi dilakukan dengan melihat nilai estimasi trace statistic yang dibandingkan dengan nilai critical value, yang dalam penelitian ini digunakan sebesar 5 persen. Persamaan terkointegrasi jika nilai trace statistic lebih besar dari critical value. Tabel 5 dan 6 . menunjukkan bahwa model inflasi dan pertumbuhan ekonomi terdapat delapan persamaan terkointegrasi

Tabel 5. Hasil Uji Kointegrasi Pertumbuhan Ekonomi

\begin{tabular}{ll}
\hline Trace Statistic & Critical Value \\
\hline 931.6694 & 228.2979 \\
682.0651 & 187.4701 \\
472.6531 & 150.5585 \\
355.5600 & 117.7082 \\
255.2115 & 88.80380 \\
171.5602 & 63.87610 \\
109.6827 & 42.91525 \\
58.04865 & 25.87211 \\
24.71641 & 12.51798 \\
\hline
\end{tabular}

Kointegrasi yang telah dilakukan, diketahui bahwa model yang tepat untuk menganalisis 464 
pengaruh jangka pendek dan jangka panjang baik model inflasi dan pertumbuhan ekonomi adalah dengan metode VECM. Panjang lag optimal yang direkomendasikan berdasarkan kriteria AIC adalah, lag 8 dipilih karena kebijakan moneter sendiri membutuhkan time lag yang cukup lama dalam mencapai sasaran akhir kebijakan ekonomi. Hasil estimasi VECM dikatakan signifikan atau mempunyai pengaruh baik untuk jangka pendek dan jangka panjang adalah ketika nilai t-Hitung lebih besar dari nilai t-tabel yang telah ditetapkan yaitu sebesar $5 \%$ atau akhir kebijakan ekonomi.

Pengaruh Jangka Pendek dan Jangka Panjang Variabel Konvensional Terhadap Inflasi

Untuk melihat pengaruh jangka pendek dan jangka panjang variabel jalur konvensional dalam mempengaruhi sasaran akhir inflasi dapat dilihat pada tabel 6.

Tabel 6. Pengaruh Jangka Pendek dan Jangka Panjang Variabel Konvensional Terhadap Inflasi

\begin{tabular}{l|l|l}
\hline \multicolumn{2}{l}{ Pengaruh Jangka Pendek } & t-Statistik \\
\hline Variabel & Koefisien & {$[1.45789]$} \\
Kredit (-5) & 1.173098 & {$[-1.32135]$} \\
Suku Bunga Kredit (-3) & -0.176185 & {$[1.43404]$} \\
Suku Bunga PUAB (-4) & 0.024401 & {$[-2.67221]^{*}$} \\
Suku Bunga SBI (-4) & -0.090701 & {$[\mathbf{7 . 4 1 6 3 4}]^{*}$} \\
\hline Pengaruh Jangka Panjang & {$[-1.86195]$} \\
Kredit & 2.753535 & {$[-2.25635]^{*}$} \\
Suku Bunga Kredit & -0.052556 & {$[-17.3274]^{*}$} \\
Suku Bunga PUAB & -0.049931 & -0.178128 \\
Suku Bunga SBI &
\end{tabular}

\section{Jangka Pendek}

Hasil untuk persamaan jangka pendek pada model dengan sasaran akhir kebijakan moneter inflasi, hanya variabel suku bunga SBI yang signifikan dalam mempengaruhi inflasi. Hasil ini menunjukkan bahwa kebijakan moneter memerlukan time lag hingga mencapai sasaran akhir yang hendak dicapai (Prasetyo,2009:122).

\section{Pengaruh Jangka Panjang}

Hasil VECM untuk jangka panjang adalah hampir semua variabel signifikan dalam mempengaruhi sasaran akhir inflasi, kecuali variabel suku bunga kredit yang tidak signifikan karena nilai t-Hitung lebih kecil dari t-Statistik 5\%. Hasil dari pengujian VECM untuk variabel kredit, suku bunga PUAB, dan suku bunga SBI signifikan dengan inflasi pada jangka panjang dikarenakan nilai t-hitung yang didapat lebih besar dari 1.986 seperti terlihat pada tabel 6 diatas. Nilai koefisien yang diperoleh masing-masing variabel konvensional dalam mempengaruhi inflasi adalah 2.753535 untuk variabel kredit yang menandakan hubungannya positif antara kredit dengan inflasi.
Hasil ini sesuai dengan alur transmisi kebijakan moneter indonesia menurut Warjiyo (2004), dimana ketika Bank Indonesia sedang dalam melakukan kebijakan ekspansi untuk meningkatkan perekonomian, kebijakan ekspansi biasanya dilakukan dengan penurunan suku bunga acuan. Penurunan suku bunga BI Rate menurunkan suku bunga kredit sehingga permintaan akan kredit dari perusahaan dan rumah tangga akan meningkat. Penurunan suku bunga kredit juga akan menurunkan biaya modal perusahaan untuk melakukan investasi. Pada akhirnya ini semua akan meningkatkan aktivitas konsumsi dan investasi saat konsumsi dan investasi ini naik maka akan menyebabkan inflasi mengalami kenaikan dari sisi permintaan.

Nilai koefisien yang diperoleh variabel suku bunga kredit, suku bunga PUAB, suku bunga SBI adalah negatif dengan masing-masing nilai sebesar -0.052556 untuk suku bunga kredit, -0.049931 untuk suku bunga PUAB, dan -0.178128 untuk suku bunga SBI hubungan ini sesuai dengan teori yang ada dimana suku bunga akan menurunkan inflasi. Hasil penelitian ini sesuai dengan alur 
transmisi kebijakan moneter Warjiyo (2004) yang ada dimana apabila suku bunga SBI/PUAB/Kredit mengalami kenaikan maka akan mendorong keinginan para pelaku ekonomi dan masyarakat untuk menggunakan uangnya untuk tujuan spekulasi yakni membeli surat berharga dari pada menggunakan uangnya untuk konsumsi, sehingga akan menurunkan inflasi.
Pengaruh Jangka Pendek dan Jangka Panjang Variabel Syariah Terhadap Inflasi

Pengaruh jangka pendek dan jangka panjang variabel syariah terhadap inflasi berdasarkan hasil estimasi VECM dapat dilihat pada tabel 7.

Tabel 7. Pengaruh Jangka Pendek dan Jangka Panjang Variabel Syariah Terhadap Inflasi

\begin{tabular}{|c|c|c|}
\hline \multicolumn{3}{|l|}{ Pengaruh Jangka Pendek } \\
\hline Variabel & Koefisien & t-Statistik \\
\hline Pembiayaan (-7) & -1.353475 & {$[-2.00704]^{*}$} \\
\hline Bagi Hasil Pembiayaan (-5) & -0.006986 & {$[-1.95878]$} \\
\hline Bagi Hasil PUAS (-4) & -0.048366 & {$[-2.04028]^{*}$} \\
\hline Bagi Hasil SBIS (-7) & $-0,016381$ & {$[-1,32571]$} \\
\hline \multicolumn{3}{|l|}{ Pengaruh Jangka Panjang } \\
\hline Pembiayaan & -3.253130 & {$[-19.2138]^{*}$} \\
\hline Bagi Hasil Pembiayaan & -0.023795 & {$[-6.43865]^{*}$} \\
\hline Bagi Hasil PUAS & -0.117820 & {$[-5.06621]^{*}$} \\
\hline Bagi Hasil SBIS & -0.099306 & {$[-4.14478]^{*}$} \\
\hline
\end{tabular}

\section{Pengaruh Jangka Pendek}

Hasil untuk persamaan jangka pendek pada model dengan sasaran akhir inflasi, hanya ada dua variabel syariah yang signifikan yaitu Bagi Hasil PUAS, dan Pembiayaan yang disalurkan. Hasil ini menunjukkan bahwa kebijakan moneter memerlukan time lag hingga mencapai sasaran akhir yang hendak dicapai (Prasetyo,2009:122).

\section{Pengaruh Jangka Panjang}

Hasil VECM untuk jangka panjang adalah semua variabel signifikan dalam mempengaruhi sasaran akhir inflasi karena nilai t-Hitung lebih besar dari t-tabel $5 \%$ seperti terlihat pada tabel 2 diatas. Koefisien yang diperoleh untuk masingmasing variabel adalah sebesar -3.253130 , untuk pembiayaan, -0.023795 bagi hasil pembiayaan, 0.117820 bagi hasil PUAS dan -0.099306 untuk bagi hasil SBIS. Nilai koefisien yang didapatkan bernilai negatif semuanya yang menandakan hubungan antara variabel syariah dan inflasi adalah negatif. Hubungan negatif antara pembiayaan dan inflasi sesuai dengan penelitian yang dilakukan oleh Ascarya (2010a) Karena pembiayaan perbankan syariah dipengaruhi oleh bagi hasilnya, sehingga pembiayaan yang disalurkan oleh perbankan syariah berdampak negatif terhadap inflasi yang ada di Indonesia. Sedangkan untuk ketiga variabel lainnya yaitu bagi hasil pembiayaan, PUAS, dan SBIS berhubungan negatif karena ketika bank sentral sedang melakukan kebijakan moneter kontraktif makan hal yang di lakukan oleh bank indonesia adalah dengan cara meningkatkan fee SBIS ketika Fee SBIS ini mengalami kenaikan, akan di respons oleh tingkat bagi hasil PUAS yang juga akan mengalami kenaikan, kenaikan pada tingkat bagi hasil PUAS akan di respons oleh tingkat bagi hasil pembiayaan yang juga akan mengalami kenaikan. Kenaikan pada bagi hasil pembiayaan akan mengurangi minat masyarakat dalam meminjam di perbankan syariah terutama pinjaman untuk konsumsi karena tingkat pengembalian yang harus dikembalikan semakin tinggi, dan lebih memilih untuk menabungkan dana yang dimilikinya. Dari hal tersebut akan mengurangi laju inflasi dari sisi permintaan. 
Pengaruh Jangka Pendek dan Jangka Panjang

Variabel Jalur Konvensional Terhadap

Pertumbuhan Ekonomi

Tabel 8. Pengaruh Jangka Pendek dan Jangka Panjang Variabel Konvensional Terhadap Pertumbuhan Ekonomi

\begin{tabular}{l|l|l}
\hline \multicolumn{3}{l}{ Pengaruh Jangka Pendek } \\
\hline Variabel & Koefisien & t-Hitung \\
\hline Kredit (-6) & 1.475749 & {$[1.25334]$} \\
Suku Bunga Kredit (-7) & -0.214466 & {$[-1.08561]$} \\
Suku Bunga PUAB (-2) & -0.026950 & {$[-0.78672]$} \\
Suku Bunga SBI (-6) & $\mathbf{- 0 . 1 5 8 5 5 4}$ & {$[-2.74018]^{*}$} \\
\hline Pengaruh Jangka Panjang & \multicolumn{2}{|l}{} \\
\hline Kredit & 2.990206 & {$[12.1016]^{*}$} \\
Suku Bunga Kredit & 0.024468 & {$[1.20492]$} \\
Suku Bunga PUAB & -0.186978 & {$[-12.8985]^{*}$} \\
Suku Bunga SBI & 0.048177 & {$[5.57399]^{*}$} \\
\hline
\end{tabular}

\section{Pengaruh Jangka Pendek}

Hasil untuk persamaan jangka pendek pada model dengan sasaran akhir kebijakan moneter pertumbuhan ekonomi, hanya variabel suku bunga SBI yang signifikan dalam mempengaruhi pertumbuhan ekonomi. Hasil ini menunjukkan bahwa kebijakan moneter memerlukan time lag hingga mencapai sasaran akhir yang dicapai (Prasetyo,2009:122).

\section{Pengaruh Jangka Panjang}

Hasil VECM untuk jangka panjang adalah hampir semua variabel signifikan dalam mempengaruhi sasaran akhir inflasi karena nilai
t-Hitung lebih besar dari t-tabel 5\% kecuali suku bunga kredit seperti terlihat pada tabel 2 diatas.

Koefisien yang diperoleh untuk masingmasing variabel adalah sebesar 2.990206 untuk kredit yang menandakan hubungan positif, 0.024468 untuk suku bunga kredit (hubungan positif), -0.186978 suku bunga PUAB (berhubungan negatif), dan 0.048177 untuk bagi hasil SBIS (berhubungan positif dengan pertumbuhan ekonomi).

Pengaruh Jangka Pendek dan Jangka Panjang Variabel Jalur Syariah Terhadap Pertumbuhan Ekonomi

Tabe1 9. Pengaruh Jangka Pendek Dan Jangka Panjang Variabel Syariah Terhadap Pertumbuhan Ekonomi

\begin{tabular}{|c|c|c|}
\hline \multicolumn{3}{|l|}{ Pengaruh Jangka Pendek } \\
\hline Variabel & Koefisien & t-Hitung \\
\hline Pembiayaan (-7) & 1.236210 & {$[1.73468]$} \\
\hline Bagi Hasil Pembiayaan (-5) & -0.007750 & {$[-1.46088]$} \\
\hline Bagi Hasil PUAS (-8) & -0.041592 & {$[-1.92520]$} \\
\hline Bagi Hasil SBIS(-4) & 0.052108 & {$[2.07009]^{*}$} \\
\hline \multicolumn{3}{|l|}{ Pengaruh Jangka Panjang } \\
\hline Pembiayaan & 1.105383 & {$[11.2695]^{*}$} \\
\hline Bagi Hasil Pembiayaan & 0.007444 & {$[3.51018]^{*}$} \\
\hline Bagi Hasil PUAS & 0.033535 & {$[2.23819]^{*}$} \\
\hline Bagi Hasil SBIS & -0.047519 & {$[-2.78902]^{*}$} \\
\hline
\end{tabular}




\section{Pengaruh Jangka Pendek}

Hasil VECM untuk jangka pendek menunjukkan bahwa hanya ada variabel fee SBIS yang signifikan. Hal ini menunjukkan bahwa kebijakan moneter membutuhkan time lag hingga mencapai sasaran akhir yang hendak dicapai (Prasetyo,2009:122)

\section{Pengaruh Jangka Panjang}

Hasil VECM untuk jangka panjang adalah semua variabel signifikan dalam mempengaruhi sasaran akhir inflasi karena nilai t-Hitung lebih besar dari t-tabel 5\% seperti terlihat pada tabel 2 diatas. Koefisien yang diperoleh untuk masingmasing variabel adalah sebesar 1.105383 , untuk pembiayaan, 0.007444 bagi hasil pembiayaan, 0.033535 bagi hasil PUAS dan -0.099306 untuk bagi hasil SBIS. Nilai koefisien yang didapatkan hampir semuanya bernilai positif yang menandakan hubungan antara variabel syariah dan pertumbuhan ekonomi adalah positif kecuali bagi hasil SBIS yang berhubungan negatif dengan pertumbuhan ekonomi di Indonesia.

Hubungan positif antara pembiayaan dengan pertumbuhan ekonomi sesuai dengan penelitian yang dilakukan Sangidi (2014) dan Ayuniyah (2010). Hubungan ini dapat dijelaskan saat adanya kebijakan moneter ekspansif. Hal ini akan menyebabkan peningkatan jumlah pembiayaan yang disalurkan, peningkatan pembiayaan dikarenakan tingkat bagi hasil SBIS mengalami penurunan yang mengakibatkan perbankan memilih menyalurkan dananya ke masyarakat dari pada menyimpannya di Bank Indonesia. Selanjutnya, peningkatan pembiayaan yang disalurkan akan menyebabkan peningkatan output perekonomian, karena dengan peningkatan pembiayaan yang disalurkan, akan semakin bayak modal yang dimiliki perusahaan dari meminjam ke perbankan, sehingga semakin banyak proses produksi yang dapat dibiayai, saat produksi mengalami kenaikan akan berakibat pada meningkatnya pertumbuhan ekonomi.

Hubungan positif antara bagi hasil pembiayaan dengan pertumbuhan ekonomi sesuai dengan penelitian ini sesuai dengan Ayuniyyah (2010) dan Noverianto (2014) yang menyatakan hubungan antara bagi hasil pembiayaan dengan pertumbuhan ekonomi adalah positif. Noverinto mengatakan bahwa semakin tinggi tingkat bagi hasil pembiayaan yang diberikan ke nasabahnya, maka akan meningkatkan pula permintaan akan pembiayaan bidang produktif yang dilakukan nasabah perbankan syariah karena jika bagi hasil dinaikkan maka bagi hasil yang didapatkan jika usahanya berhasil akan semakin tinggi yang secara otomatis akan mendorong meningkatnya pertumbuhan ekonomi yang akan berpengaruh pada produk domestik bruto suatu negara.

Hubungan positif antara bagi hasil PUAS dengan pertumbuhan ekonomi sesuai dengan Penelitian yang dilakukan Ascarya (2010a dan 2010b) yang menyatakan bahwa setiap ada kenaikan bagi hasil PUAS akan meningkatkan pertumbuhan ekonomi hubungan positif ini dikarenakan saat tingkat bagi hasil PUAS dinaikkan akan menyebabkan kenaikan pada tingkat bagi hasil pembiayaan pada perbankan syariah, saat tingkat bagi hasil pembiayaan dengan akad Al-Musyarakah dan Al-Mudharabah mengalami kenaikan maka akan menambah minat masyarkat untuk melakukan pinjaman produktif di perbankan syariah yang pada akhirnya akan meningkatkan pertumbuhan ekonomi.

Hubungan negatif antara bagi hasil SBIS dengan pertumbuhan ekonomi sesuai dengan Penelitian yang dilakukan Ayuniyyah (2010) dan Sangidi (2014) dimana setiap ada kenaikan fee SBIS akan menurunkan pertumbuhan ekonomi dalam jangka yang panjang, ini dikarenakan merupakan cerminan dari karakteristik SBIS dimana akan menyerap dana yang tidak tersalurkan pada sektor riil, sehingga kedua nilai ini akan kontra terhadap nilai tumbuhan ekonomi.

\section{Uji Kausalitas Granger}

Uji kausalitas Granger dalam penelitian ini digunakan untuk melihat hubungan antar variabel apakah mempunyai hubungan satu arah, dua arah ataupun tidak ada hubungan keduanya. Yang kemudian dari hasil kausalitas tersebut dibuat sebuah mekanisme transmisi kebijakan moneter baik dari jalur syariah ataupun jalur konvensional.

\section{Alur Mekanisme Transmisi Kebijakan Moneter Konvensional dengan Sasaran Inflasi dan Pertumbuhan Ekonomi}


Gambar 2. merupakan mekanisme transmisi kebijakan moneter jalur konvensional dengan sasaran akhir inflasi dan pertumbuhan ekonomi yang dapat dibentuk dari hasil granger causality. transmisi kebijakan moneter jalur konvensional sudah sesuai dengan teori kebijakan moneter yang diungkapkan oleh Warjiyo (2004) dalam bukunya. Dimana mekanisme transmisi nya adalah ketika bank sentral sedang dalam melakukan kebijakan ekspansi yaitu untuk meningkatkan perekonomian. Maka bank sentral akan menurunkan suku bunga SBI, yang kemudian akan di respons oleh suku bunga PUAB, penurunan suku bunga PUAB akan

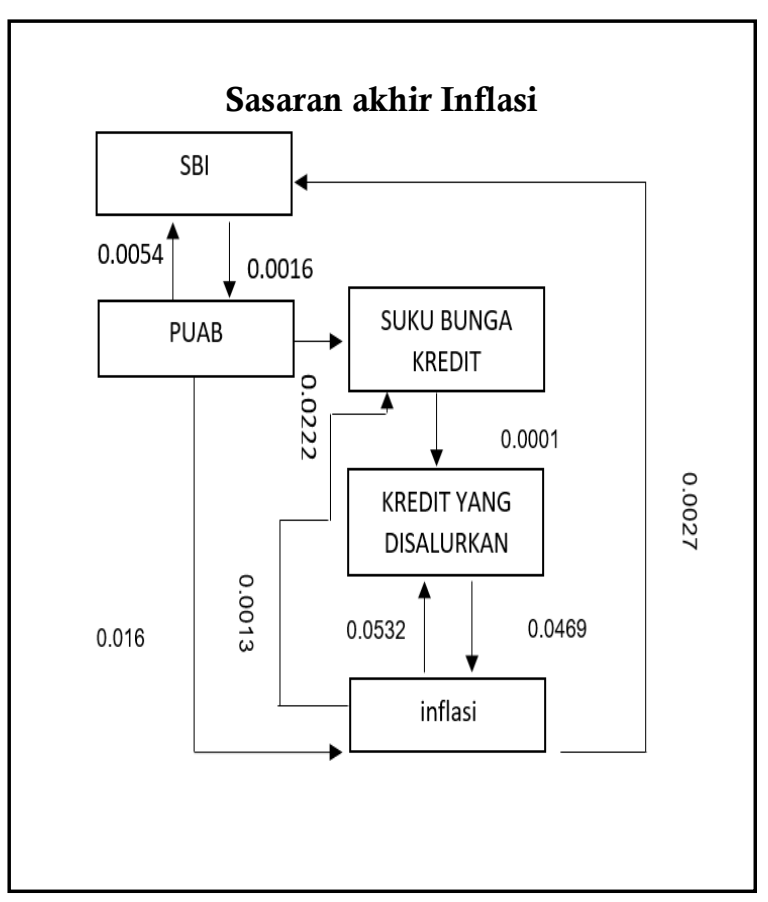
Hasil pada gambar 2 menunjukkan mekanisme

berdampak pada penurunan tingkat suku bunga kredit yang menjadikan permintaan akan kredit dari perusahaan dan rumah tangga meningkat baik untuk modal kerja ataupun untuk aktivitas konsumsi. Yang pada akhirnya akan meningkatkan aktivitas konsumsi dan investasi saat konsumsi dan investasi naik maka akan menyebabkan pertumbuhan ekonomi dan meningkatkan inflasi, saat inflasi hampir melebihi target yang telah ditentukan bank Indonesia akan merespons dengan instrumen SBI nya untuk meredam inflasi tersebut. Dan mekanisme kebijakan moneter tersebut akan berputar kembali.

\section{Sasaran akhir Pertumbuhan Ekonomi}

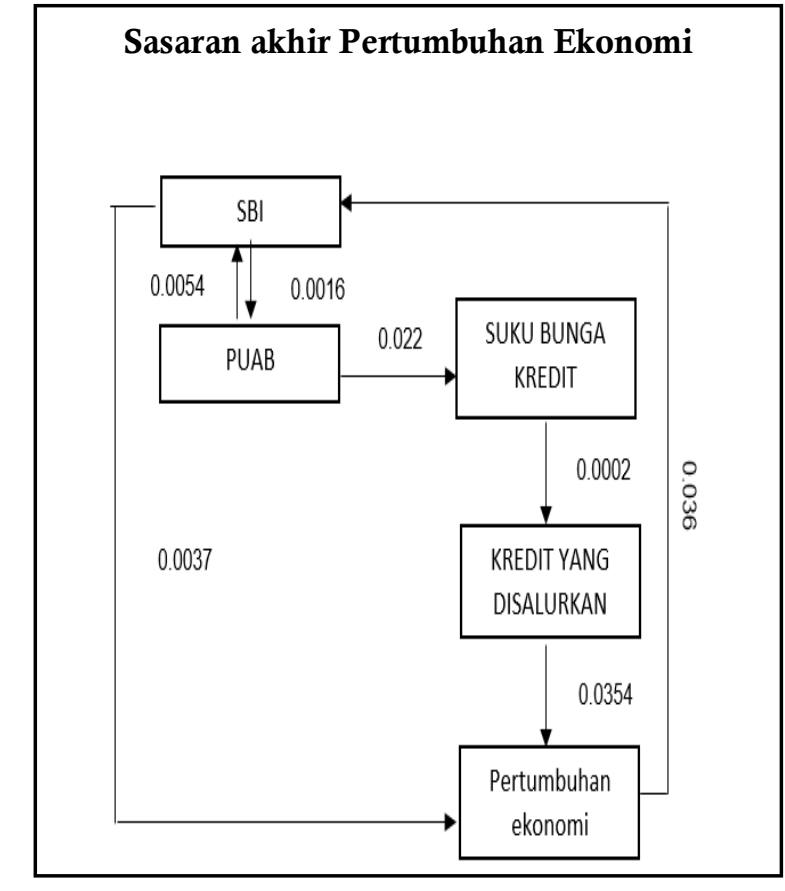

Gambar 2. Alur Mekanisme Transmisi Kebijakan Moneter Jalur Konvensional dengan Sasaran Akhir Inflasi dan Pertumbuhan Ekonomi

Gambar 3. merupakan mekanisme transmisi kebijakan moneter jalur syariah dengan sasaran akhir inflasi dan pertumbuhan ekonomi yang dapat dibentuk dari hasil granger causality. Hasil pada gambar 5 menunjukkan mekanisme transmisi kebijakan moneter jalur syariah, Jalur syariah belum menunjukkan alur kebijakan moneter yang seharusnya seperti model yang di ungkapkan oleh daniar (2016:99) dimana mekanisme transmisi kebijakan moneter pada gambar 5 terhenti pada inflasi dan pertumbuhan ekonomi. Padahal yang seharusnya adalah inflasi dan pertumbuhan ekonomi mempengaruhi fee dari SBIS, sehingga akan menjadikan sebuah mekanisme transmisi kebijakan moneter yang berkesinambungan. 
Alur Mekanisme Transmisi Kebijakan Moneter Syariah dengan Sasaran Akhir Inflasi dan Pertumbuhan Ekonomi.
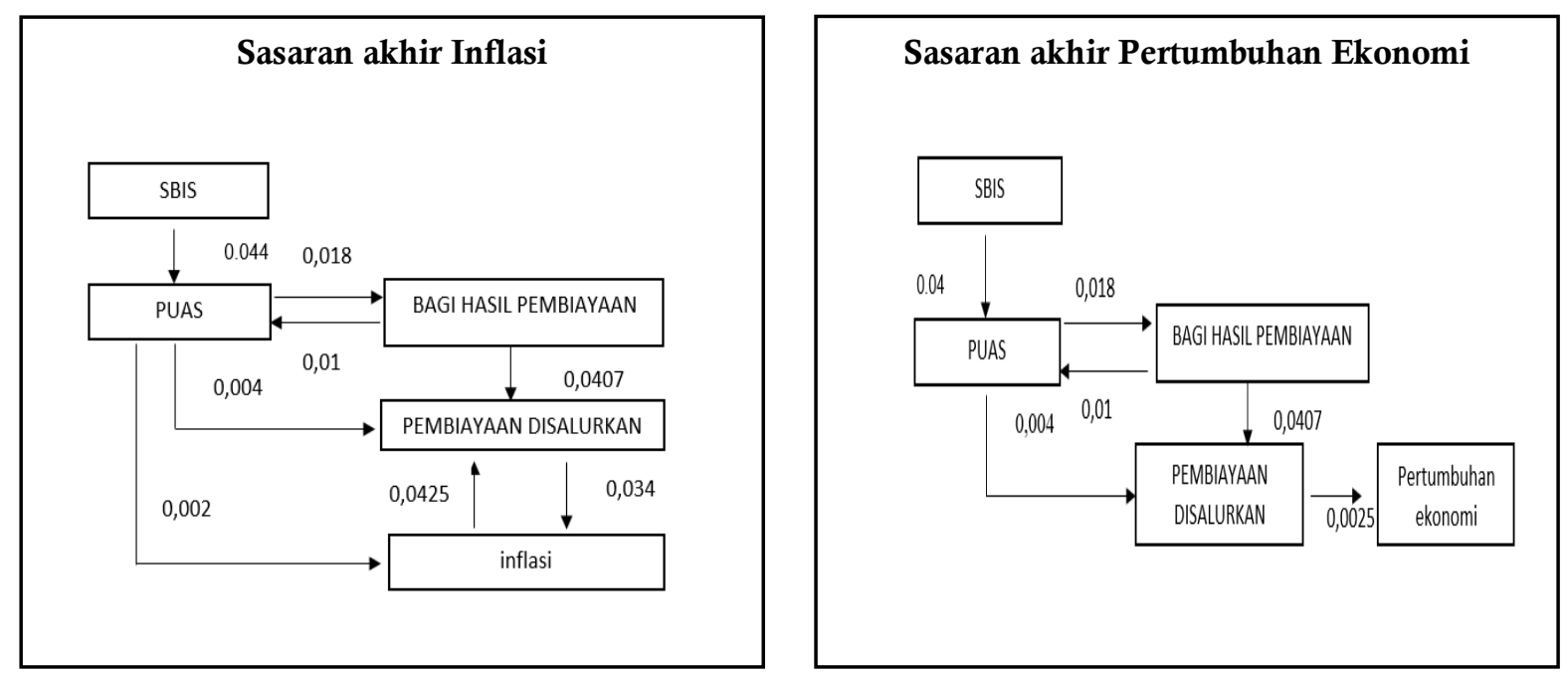

Gambar 3. Mekanisme Transmisi Kebijakan Moneter Jalur Sariah dengan Sasaran Akhir Inflasi dan Pertumbuhan Ekonomi

Hasil ini mirip dengan penelitian yang dilakukan Ascarya (2010) dimana alur mekanisme transmisi kebijakan moneter jalur syariah belum mempunyai hubungan yang jelas dimana terhenti pada inflasi, padahal seharusnya inflasi akan mempengaruhi SBIS. Menurut Ascarya (2010) Tidak adanya kesinambungan pada mekanisme transmisi kebijakan moneter jalur syariah dalam mempengaruhi sasaran inflasi dikarenakan hingga pada tahun 2008 tingkat fee SWBI tidak mengacu pada SBI konvensional dan nilai SWBI hingga pada tahun 2008 nilainya cenderung kecil, yang menyebabkan masyarakat tidak terlalu menyukai SWBI untuk berinvestasi.

\section{Uji Forecast Error Variance Decomposition (FEVD)}

Struktur dinamis antar variabel dalam VAR dapat dilihat melalui analisis Forecasting Error Variance Decomposition (FEVD), dimana pola dari FEVD ini mengindikasikan sifat dari kausalitas multivariat di antara variabel-variabel dalam model VECM. Pengurutan variabel dalam analisis FEVD ini didasarkan pada faktorisasi Cholesky. FEVD dalam penelitian ini juga untuk melihat perbandingan kecepatan dalam merespons sasaran akhir kebijakan moneter yaitu inflasi dan pertumbuhan ekonomi antara variabel syariah dengan variabel konvensional.
Hasil FEVD Sampai bulan ke-40, atau pada masa akhir peramalan fluktuasi inflasi masih dominan dipengaruhi oleh guncangan inflasi itu sendiri dengan nilai sebesar $60 \%$. ini mengindikasikan bahwa mekanisme transmisi kebijakan moneter baik pada jalur syariah (pembiayaan perbankan syariah) dan jalur konvensional (kredit perbankan konvensional) tidak memberikan efek yang besar terhadap inflasi, ini bisa disebabkan karena mekanisme transmisi kebijakan moneter di Indonesia mempunyai lima jalur lainnya dalam menstabilkan inflasi. Lima jalur tersebut yaitu suku bunga, nilai tukar, ekspektasi, harga aset dan permintaan uang.

Kontribusi variabel jalur konvensional terhadap inflasi adalah sebesar $19,97 \%$ dengan komposisi suku bunga kredit sebesar 4,81\%, kredit yang disalurkan 4,07\%, suku bunga PUAB 6,06\% dan suku bunga SBI sebesar 5,03\%. Untuk variabel jalur syariah memiliki kontribusi terhadap inflasi sebesar $19,47 \%$ dengan komposisi pembiayaan sebesar $6,32 \%$, bagi hasil pembiayaan $5,59 \%$, bagi hasil PUAS $0,41 \%$ dan bagi hasil SBIS sebesar 7,15\%. Dilihat dari hasil FEVD sampai bulan terakhir peramalan efek guncangan variabel jalur konvensional lebih besar pengaruhnya dibandingkan dengan variabel jalur syariah. Akan tetapi dengan share perbankan syariah yang hanya $5 \%$ di Indonesia (OJK, 2015) dibandingkan 
perbankan konvensional yang mempunyai share sebesar 95\%. Ini membuktikan bahwa perbankan syraiah mempunyai andil yang sangat besar dalam

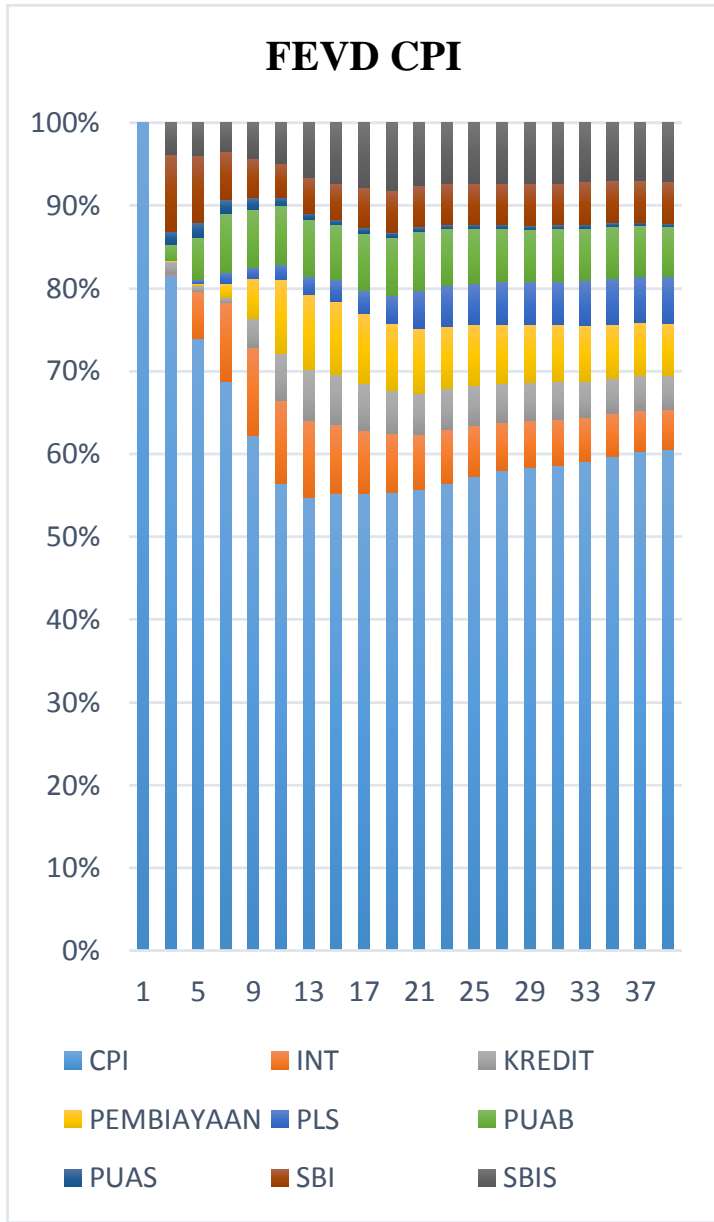

mekanisme transmisi kebijakan moneter kebijakan moneter di Indonesia terutama dalam mempengaruhi sasaran akhir inflasi.

\begin{tabular}{|c|c|c|}
\hline \multirow[t]{2}{*}{ Variabel } & \multicolumn{2}{|c|}{ Besaran VD \% } \\
\hline & Syariah & Konv. \\
\hline INFLASI & \multicolumn{2}{|l|}{$60 \%$} \\
\hline INT & & $4.81(-)$ \\
\hline Kredit & & $4.07(+)$ \\
\hline Pembiayaan & $6.32(-)$ & \\
\hline PLS & $5.59(-)$ & \\
\hline PUAB & & $6.06(-)$ \\
\hline PUAS & $0.41(-)$ & \\
\hline SBI & & $5.03(-)$ \\
\hline SBIS & $7.15(-)$ & \\
\hline Jumlah & $19.47 \%$ & $19.97 \%$ \\
\hline
\end{tabular}

Gambar 4. Variance Decomposition dengan Sasaran Akhir Inflasi

Hasil FEVD Sampai dengan bulan ke-40, fluktuasi pertumbuhan ekonomi sudah tidak dominan dipengaruhi oleh guncangan pertumbuhan ekonomi itu sendiri, efek guncangan variabel jalur konvensional dan variabel jalur syariah justru lebih besar dibandingkan pengaruh pertumbuhan ekonominya sendiri. Nilai pengaruh variabel jalur konvensional terhadap pertumbuhan ekonomi pada bulan ke-40 adalah sebesar 50,56\% dengan komposisi suku bunga kredit sebesar 6,04\%, kredit 3,49\%, suku bunga PUAB 21,93 dan suku bunga SBI sebesar 19,10\%. Dan untuk variabel jalur syariah sampai dengan bulan ke-40 memiliki pengaruh sebesar $29,07 \%$ dengan komposisi pembiayaan sebesar $13,39 \%$, bagi hasil pembiayaan $13,39 \%$, bagi hasil PUAS $0,64 \%$ dan bagi hasil SBIS 2,43\%.

Dilihat hasil FEVD dari bulan ke-12, ke-27 dan ke-40 efek guncangan variabel jalur konvensional lebih besar dibandingkan dengan variabel jalur syariah. Jadi dilihat dari hasil FEVD terhadap pertumbuhan ekonomi maka dapat disimpulkan bahwa variabel jalur konvensional lebih besar pengaruhnya terhadap pertumbuhan ekonomi dibandingkan dengan variabel jalur syariah. Ini dikarenakan share perbankan konvensional yang besar di Indonesia, dimana share perbankan konvensional mencapai 95\%. 


\section{Forecast Error Variance Decomposition Pertumbuhan Ekonomi}

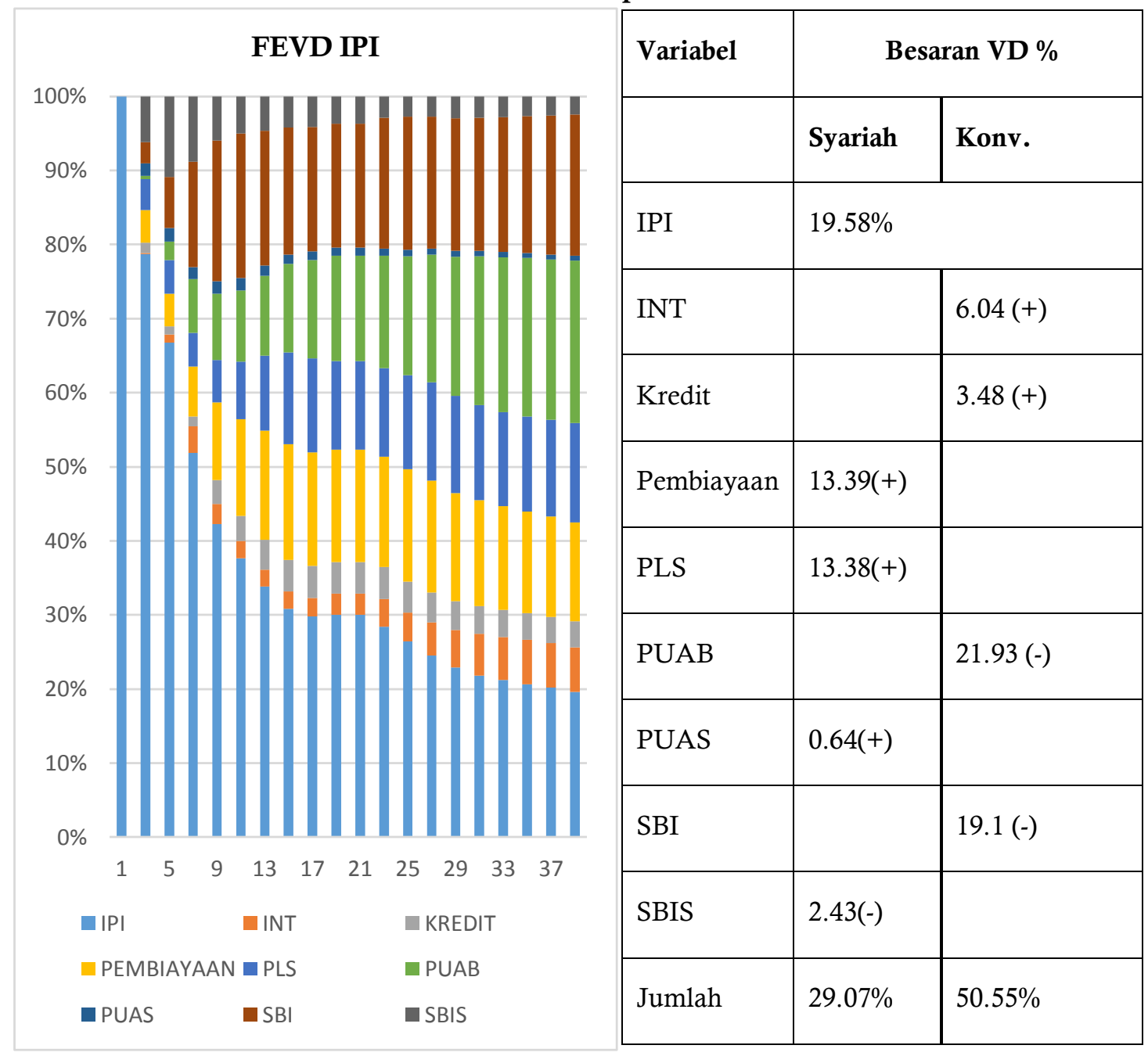

Gambar 5. Variance Decomposition dengan Sasaran Akhir Pertumbuhan Ekonomi 


\section{SIMPULAN}

Berdasarkan hasil penelitian yang telah dilakukan penulis mengenai mekanisme transmisi kebijakan moneter konvensional dan syariah dalam mempengaruhi inflasi dan pertumbuhan ekonomi, dapat disimpulkan sebagai berikut:

Secara keseluruhan, alur kebijakan moneter jalur konvensional sesuai dengan teori baik untuk sasaran akhir pertumbuhan ekonomi ataupun inflasi, sedangkan alur transmisi kebijakan moneter jalur syariah belum sesuai dengan teori, ini bisa disebabkan karena tingkat SWBI/SBIS masih terbilang kecil dan belum bisa bersaing dengan tingkat suku bunga SBI konvensional.

Pengaruh dalam jangka pendek baik untuk jalur konvensional dan syariah tidak signifikan yang membuktikan bahwa mekanisme transmisi kebijakan moneter membutuhkan waktu/ time lag dalam mencapai sasaran akhir baik inflasi ataupun pertumbuhan ekonomi. sedangkan untuk pengaruh jangka panjang dari variabel jalur syariah terhadap Inflasi dan pertumbuhan ekonomi adalah positif, yang artinya variabel jalur syariah dapat mengurangi inflasi dan meningkatkan pertumbuhan ekonomi dalam waktu yang bersamaan. Sedangkan pengaruh dari variabel jalur konvensional adalah dapat mengurangi inflasi akan tetapi menurunkan pertumbuhan ekonomi dalam jangka yang panjang.

Dari hasil FEVD menunjukkan variabel jalur konvensional lebih besar pengaruhnya terhadap sasaran akhir kebijakan moneter dengan kontribusi sebesar 50,5\% untuk pertumbuhan ekonomi dan 19,97\% untuk inflasi. Sedangkan untuk variabel syariah hanya menyumbang sebesar $29.07 \%$ untuk pertumbuhan ekonomi dan 19,97 untuk inflasi.

\section{DAFTAR PUSTAKA}

Ascarya. 2010a. Transmission Channel And Effectiveness Of Dual Monetary Policy In Indonesia. Working Paper. Bank Indonesia

Ascarya. 2010b. Roles of Indonesia's Islamic Banking in Achieving Macro Economic Objectives. Paper dipresentasikan pada International
Summit Ikatan Ilmuwan Indonesia Internasional (I-4) "Pengelolaan Sumber Daya Ekonomi Menuju Indonesia Maju dan Mandiri Melalui perkembangan Ilmu Ekonomi Terbaru", Jakarta 16-19 Desember 2010.

Aydin, Celil,et al. 2016. Inflation and Economic Growth: A Dynamic Panel Threshold Analysis for Turkish Republics in Transition Process. Procedia - Social and Behavioral Sciences, 229, pp.196-205.

Ayuniyyah Q. 2010. Analisis Pengaruh Instrumen Moneter Syariah dan Konvensional terhadap Pertumbuhan Sektor Riil di Indonesia [Skripsi]. Bogor (ID): IPB Press

Bank Indonesia. Indikator Ekonomi dan Keuangan. Berbagai Terbitan 2005-2015. Jakarta: Bank Indonesia

............... Statistik Ekonomi dan Keuangan Indonesia. Berbagai Terbitan 2005-2015. Jakarta: Bank Indonesia Statistik Perbankan Indonesia. Berbagai Terbitan 2005-2015 Jakarta: Bank Indonesia.

Baharumshah, Ahmad Zubaidi, et al. 2016. Inflation, inflation uncertainty, and economic growth in emerging and developing countries: Panel data evidence. Economic Systems, 40, pp.638-657.

Beik, Ayuniyyah, dan Arsyianti. 2013. Dynamic Analysis of Islamic Bank and Monetary Instrument towards Real Output and Inflation in Indonesia. Proceeding of Sharia Economics Conference-Hannover, 9 February 2013.

Dahlan Siamat, 2004. Manajemen Lembaga Keuangan, Edisi Keempat, Lembaga Penerbit Fakultas Ekonomi Universitas Indonesia

Daniar,2016. Transmisi Kebijakan Moneter Syariah: Sebuah Analisa. Falah Jurnal Ekonomi Islam Vol. 1, No.1, Februari 2016.

Mohseni, Mehrnoosh and Feizolah Jouzaryan. 2016. Examining the Effects of Inflation and Unemployment on Economic Growth in Iran (1996-2012). Procedia Economics and Finance, 36, pp.381-389.

Otoritas Jasa Keuangan. Statistik Perbankan Syariah Indonesia. Berbagai Terbitan 2005-2015. Jakarta. Otoritas Jasa Keuangan

Otoritas Jasa Keuangan. Statistik Perbankan Indonesia. Berbagai terbitan 2005-2015. Jakarta. Otoritas Jasa Keuangan.

Prasetyo, P.Eko. 2009. Fundamental Makro Ekonomi. Yogyakarta: Betta Offse

Pratiwi, Nabilla mardiana dkk. 2015. Pengaruh Inflasi, Tingkat Suku Bunga Sbi, Dan Nilai Tukar Terhadap Penanaman Modal Asing Dan 
Pertumbuhan Ekonomi di Indonesia. Jurnal Administrasi Bisnis (JAB) Vol. 26 No. 2, september 2015

Sangidi, Wulandari. 2014. Efektivitas Mekanisme Transmisi Moneter Melalui Jalur Pembiayaan Bank Syariah Di Indonesia [Skripsi]. Fakultas Ekonomi dan Manajemen. Instittut Pertanian Bogor

Septifany, Aminda Tri dkk. 2015. Pengaruh Inflasi, Tingkat Suku Bunga Sbi, Dan Nilai Tukar Terhadap Penanaman Modal Asing di Indonesia. Jurnal Administrasi Bisnis (JAB) ,Vol. 26 No. 2, september 2015

Wirjiyo, Perry. 2004. Mekanisme Transmisi Kebijakan Moneter di Indonesia. Pusat Pendidikan dan Studi Kebanksentralan. Bank Indonesia

Qolby, M.. Faktor - Faktor Yang Mempengaruhi Pembiayaan Pada Perbankan Syariah Di Indonesia Periode Tahun 2007 - 2013.

Economics Development Analysis Journal. 